\title{
Serial Verb Construction in Etulo
}

\author{
Chikelu Ihunanya Ezenwafor \\ Department of Linguistics, Nnamdi Azikiwe University, Awka, Nigeria
}

\begin{abstract}
In languages, different criteria are often adopted in the classification of the verb category many of which are language specific or universal. Etulo makes a distinction between simple and complex predicates. This work discusses serial verb construction (SVC) as a type of complex predicate using the typological criteria proposed in Aikhenvald (2006). Etulo SVCs have diverse semantic and grammatical functions. They express benefactive, instrumental, comparative meaning, as well as prepositional and adverbial notions indicating direction using motion verbs. Different types of serial verb constructions (SVCs) are established: the symmetric vs asymmetric type, contiguous vs non-contiguous, and the optional vs obligatory type. The SVC is further distinguished from a similar multi-verb construction known as the consecutive construction.
\end{abstract}

Index Terms - complex predicate, serial verb, lexicalisation, Etulo

\section{INTRODUCTION}

Verb serialization has long been typologically established as an areal feature of many West African languages, especially of Kwa, Benue Congo and Gur subgroups. It is equally attested in other language families like Oceanic and Australian. Etulo, (a West African language) is characterized by a rich class of serial verbs. Overtime, some of these verbs have become grammaticalized and lexicalized. The structure of this work is given as follows: $\S 1.2$ provides some ethnolinguistic information on Etulo, $\$ 2.0$ gives an overview of the typological characterization of SVCs. In $\$ 3$ and 4, I discuss verb serialization in Etulo with emphasis on its functional properties and characterization. In $\$ 5$ SVCs are classified into types. They are further distinguished from consecutive constructions in $\S 6$. This is followed by the conclusion in $\$ 7$.

\section{Ethnolinguistic information}

Etulo is classified as an Idomoid language of the Benue Congo subgroup of the Niger Congo language family. It is a minority language spoken in some parts of Benue and Taraba states in Nigeria. This study focuses on the variety spoken in the Etulo speech community of Buruku LGA in Benue state. It is relatively under described and has yet no generally accepted standard variety and orthography. The data used here are therefore represented using the International Phonetic Alphabet. Etulo coexists alongside some other languages like Tiv, Hausa, Idoma, Igede etc. which are all spoken in Benue state and are more dominant. Etulo native speakers are mostly bilingual.

\section{The TYPOLOGICAL CRITERIA}

Aikhenvald (2006) defines a serial verb construction as a sequence of verbs which act together as a single predicate, without an overt marker of co-ordination, subordination, or syntactic dependency of any other sort. SVCs describe what is conceptualised as a single event. This view of SVCs has come under criticisms by recent works of Baker and Harvey (2014) who view SVCs as being multi-predicational. They regard the conceptual structure of SVCs as one in which there are multiple events in a monoclausal construction. Supporting this view, Foley (2014) claims that SVCs are in no sense a unified phenomenon but rather express diverse types of event structures ranging from simple to multiple or much more complex events. Notwithstanding the divergent views, it is generally agreed that SVCs obligatorily involve a sequence of verbs occurring in a single clause.

I adopt here Aikhenvald (2006) typological framework for SVCs in which she proposes different parameters for the classification of SVCs. These parameters are based on the composition of the SVC components, contiguity vs noncontiguity of components and the wordhood of SVCs. On the basis of the composition of an SVC, a two way split is made between asymmetric and symmetric types. Symmetric SVCs involve verb combinations from an unrestricted semantic class and typically denote subevents following a temporal sequence. On the other hand, asymmetric SVCs involve components from both restricted and unrestricted classs and typically denote single events. The verb from the closed (restricted class) often functions as a modifier in its occurrence with the main verb.

Below are some typical characterizations of SVCs across the worlds' languages as summed up by Aikhenvald:

- Monoclausality

- A sequence of two or more contiguous or non-contiguous verbs in a clause

- Absence of any marker of syntactic dependency

- The individual verbs can function as independent verbs in simple clauses

- Shared tense, aspect, mood, modality, negation

- Verbs share a single subject

- Components of SVCs cannot be questioned separately 
The 'absence of any marker of syntactic dependency' as a prototypical feature of SVCs can be problematic in some languages where there are other multi-verb structures such as consecutive, overlapping and even conjoined structures (existing alongside SVCs) that lack markers of syntactic dependency as well. This is evident in Goemai (a West Chadic language) in which syntactic dependency markers are absent in both SVCs and conjoined structures (cf Hellwig 2006). This is also observed in Etulo as briefly discussed in $§ 6$. Such languages therefore adopt other language internal means for distinguishing between SVCs and other multi-verb structures.

There are however, instances where individual languages with SVCs exhibit features that contradict a few of these prototypical features. In Ewe (a West African language), Ameka (2006) observes that although components of an SVC cannot be individually marked for propositional questions, they can be separately questioned using the content question strategy. In the following example from Ewe, the verbs $d a$ 'cook' and $d u$ 'eat' are separately questioned. To question a VP or happening requires the phrase $n u k a$ 'what' and the function verb $w \supset$ 'do'.
1a) $\mathrm{Nu} \quad \mathrm{ka}$ wo-da nu-a ko wo
thing INTER 3SG-cook thing-DEF take do
'What did she cook the food and do?'

1b) $\mathrm{Nu}$ ka wo-wo du
thing INTER 3SG-do eat
'What did she do and eat?'

(Ameka, 2006, p.140)

In addition to this prototypical characterization of SVCs, individual languages may have additional criteria for identifying or characterizing SVCs which would differ from one language to the other. Serial verb constructions express several nuances of meaning which include (but are not restricted to) direction, manner, comparison, benefactivity, causation, and resultative meaning. From a cross-linguistic perspective, certain serial verbs like take and give are considered more common than others. Serial verb constructions in Etulo are examined in the light of the above typological characterization.

\section{Verb SERIALIZATION IN ETUlo}

In Etulo a SVC basically refers to verb series in a monoclause that expresses unified or complex events which may be expressed by single verbs in many other languages. Most typical characterizations of SVCs across languages hold in Etulo in addition to its peculiar feature. SVCs generally comprise a minimum of two verbs in Etulo but could contain as many as three verb series or more especially in narrative contexts. The most frequently occurring serial verbs (attested

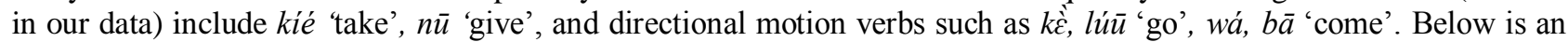
example culled from a narrative which gives an elaborate description of the subevents involved in the overall event of returning from church to one's home. Emphasis is on the main clause;

2) ní àdúà wá ńgīe, ánî kà tás $\hat{\varepsilon}$ jìdó lú-bā údé if church come finish 1SG:SUBJ FUT come out return go-come home 'If the mass ends, I will return home

\section{A. Functional Properties of SVCs}

Serial verbs express a variety of meanings including benefactivity, instrumental (kié 'take'), and comparative ( $\eta a ̀$ 'surpass) meaning. They also express prepositional and adverbial notions indicating direction using motion verbs. Note that any of these verbs could serve as the sole predicate in a grammatical construction. The functional properties of SVCs are shown in the following examples:

\section{Benefactive meaning}

The benefactive SVC is characterized by the verb $n u$ 'give' as a benefactive marker. The indirect object benefits from the action of the subject NP.

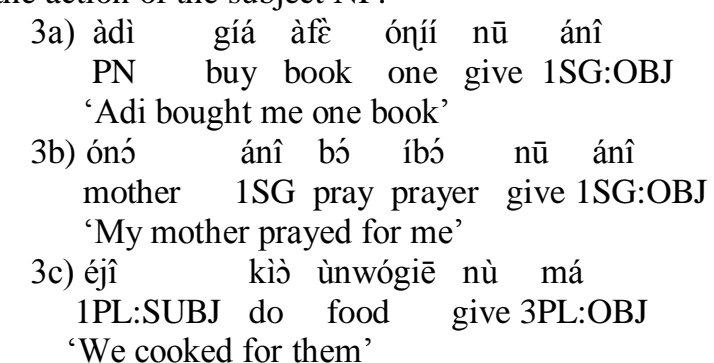

\section{Instrumental meaning}

This type of SVC is marked by the verb kié 'take'. It denotes the manner or instrument with which an event or activity is carried out. In (4a) for instance, the event of frightening is achieved by the use of a snake.
4a) ani kie ifa le wo ma imio 1SG:SUBJ take snake PROG put 3PL:OBJ fear 'I am frightening them with a snake' 
4b) adi kie mbue k1 unwogie

PN take meat do food

'Adi cooked food with meat'

\section{Accompaniment}

This type of SVC indicates that the subject NP takes the object along to specific location.

5) ánî kíe àfè kè ùmákárántá

1SG:SUBJ take book go school

'I went to school with a book'

\section{Prepositional meaning (direction/motion)}

This type of SVC is characterized by motion verbs that perform the grammatical function of prepositions. They mostly occur before nouns and indicate the direction in which an action takes place.
6a) àdì lè dó ésó bā mbí éjî
PN PROG send message come to 1PL:OBJ
'Adi is sending a message to us'
6b) ánî lè dó Ésó kè m̀bó má
1SG:SUBJ PROG send message go to 3PL:OBJ
'I am sending a message to them'

\section{Adverbial meaning}

SVCs are used to denote semantic notions encoded in other languages by adverbs such as away, down etc. The motion verb l'ú ' 'go' functions as a modifier to the main verb.

$\begin{array}{ccll}\text { 7a) ínwúnô bùlù } & \text { lú } & \text { wà } \\ \text { bird } & \text { fly } & \text { go } & \text { PERF }\end{array}$

'The bird has flown away'

7b) àdì lé tsàmú ánî lú èsé

PN PROG push 1SG:OBJ go ground

'Adi is pushing me down'

\section{Comparative and superlative meaning}

Degree is expressed using the verb $\eta \grave{a}$ 'surpass'. The position of the minor verb $\eta a$ in relation to the main verb is post verbal. Example (8a) illustrates the use of $y a$ as a comparative marker where it is preceded by the main verb gigiè 'be sharp'. For the superlative construction, ya is used in combination with dú $\bar{u}$ 'all' (8b).
$\begin{array}{cccccc}\text { 8a) èbà ḿgbì ìsèsé } & \text { gígíè yà mín ánî } \\ \text { knife } & \text { POSS } & \text { PN be sharp surpass POSS } & 1 \text { PSG }\end{array}$
'Isese's knife is sharper than mine'
$8 b)$ èbà ḿgbī ìsèsé gígíè yà dúú knife POSS PN be sharp surpass all
'Isese's knife is the sharpest'

\section{Completive meaning}

The verb of completion ìgić 'finish' pairs with many verbs in SVCs to indicate the completion of an event. It shares same temporal values with the main verb. Consider the following examples:
9a) àdi gìè ùnwógīê ǹgíć plé
PN eat food finish early
'Adi finished eating on time'
$9 \mathrm{~b})$ àdì gíé ùnwógīē ǹgíć wà
PN eat food finish PERF
'Adi has finished eating'

\section{B. SVCs and Grammaticalization}

There are two Etulo verbs that seem to be on a grammaticalization path; the speech verb, $g \boldsymbol{b} \check{\varepsilon} \bar{\varepsilon}$ 'say' and the motion verb, $k \grave{\varepsilon}$ 'go'. The use of verb 'say' as a complementizer in many West African languages is a relatively common pattern (see Lord 1993, Aikhenvald 2006). It has been the practice of some linguists to analyse this verb as a SVC or as a grammaticalized verb depending on the language (cf. Yeung 2003, Matthew 2006). In Etulo complement clause, the verb gběć 'say' functions as a complementizer with a restricted number of predicates such as jé 'know', $f o$ ' hear', $d i$ 'see' and in copula constructions. Apparently, it has been desemanticized (having lost its original meaning as a speech verb) and now assumes the grammatical function of introducing a clause. It is analysed here as a complementizer rather than a component of a SVC partly because its occurrence and grammatical function is not restricted to 'superficial' SVCs. In (10a) and (10b), one observes that the verb gběč 'say' co-occurs with the stative verbs jé 'know' and fó 'hear' in constructions that seem like SVCs. In contrast, gběc occurs in a copula construction where its function as a complementizer is retained (see 10c). In all instances of its occurrence, the original meaning is lost. Unlike the

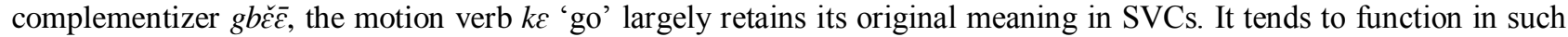


contexts as a directional marker (see $11 \mathrm{a}$ and $11 \mathrm{~b}) .{ }^{1}$ Examples:

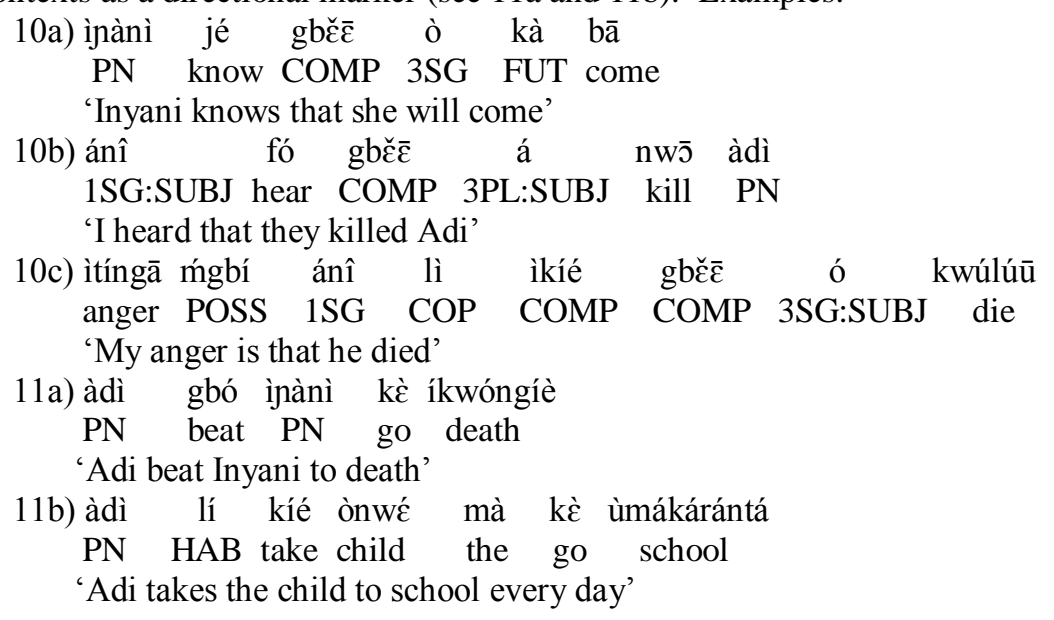

\section{Characterization OF SVCS}

Most of the typological features of SVCs articulated in Aikhenvald (2006) are attested in Etulo. They are discussed in the subsequent sections.

\section{A. Monoclausality}

SVCs in Etulo constitute a single clause with no marker of syntactic dependency. This however does not seem to be a peculiar feature of Etulo SVCs. With SVCs, the insertion of such marker of syntactic dependency as illustrated in examples (12a) - (12c) yields ungrammatical sentences. ${ }^{2}$ Even though an Etulo SVC may be defined in terms of monoclausality and the absence of a syntactic dependency marker, such characterization is not restricted to SVCs but may be extended to include a subset of consecutive constructions (see §6.0). In addition to the presence vs absence of a syntactic dependency marker, other distinctive parameters for distinguishing between both constructions are required.

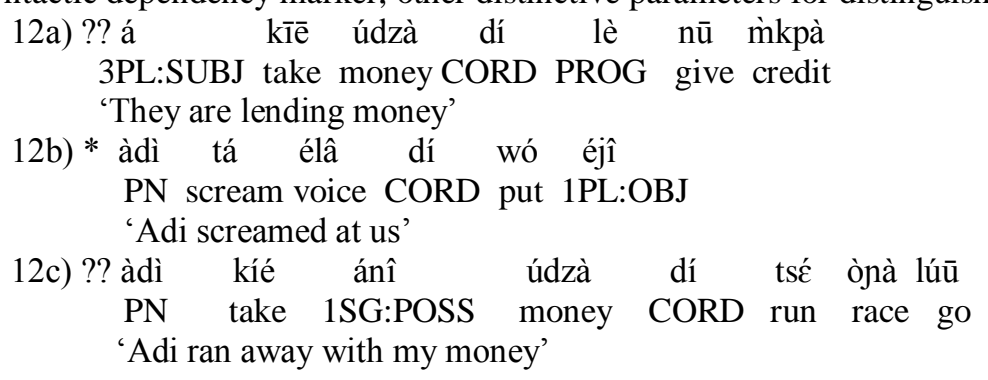

\section{B. Argument Sharing}

Argument sharing is a core feature of Etulo serial verbs. Both subject and object arguments may be shared. While subject sharing is applicable to both transitive and intransitive verbs, object sharing is restricted to transitive verbs.

\section{Subject sharing}

Subject sharing seems to be the most common form of argument sharing in Etulo. In a SVC, the verbs (whether transitive or intransitive) obligatorily share the same subject. This is illustrated with the serial verbs in (13a) and (13b).
13a) àdí kìkíč lú wà
PN walk go PERF
'Adi has walked away'

13b) ánî kà tásé jìdó lú-bā údé

\footnotetext{
${ }^{1}$ Note that the use of $k \grave{\varepsilon}$ is not required in its causative counterpart. Compare the two examples below:

i) ánî nū àdì gbó ìsès

1SG:SUBJ make PN beat PN go death

'I made Adi beat Isese to death'

ii) ánî nū àdì gbó-nwō ìsèsé

1SG:SUBJ make PN beat-kill PN

'I made Adi kill Isese'

The grammaticalization of $k \dot{\varepsilon}$ is more evident in some compound verbs where its function shifts from denoting direction to indicating a location or

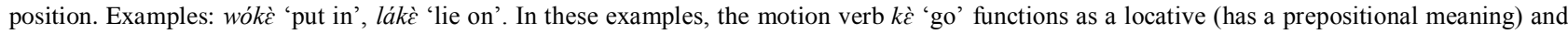
seems to have no direct semantic link with its original meaning.

${ }^{2}$ The double question mark is used in examples (12a and 12c) to specify that though the constructions do not pass as SVCs, they may possibly receive a consecutive or coordinate interpretation. For instance, (12c) would be interpreted as Adi took my money and ran away rather than Adi ran away with my money. The first interpretation indicates that the verb series express two different but sequential events while the second interpretation gives the verb series a unified meaning.
} 
1SG:SUBJ FUT come out return go-come home

'I will return home'

2. Object sharing (Same subject-same object)

Object sharing is a feature of some transitive verbs in SVCs. In (14a) for instance, the verbs kie 'take and fue 'sprinkle' share the object argument eni 'water'. This is replicated in (14b).

$14 \mathrm{a})$ ìsèsé kié ènì lè fúé

PN take water PROG sprinkle

'Isese is sprinkling water'

14b) ń kà kíe fàwá àfè méní ámá

1SG:SUBJ FUT take tear cloth of them

'I will tear their clothes

3. Arguments and switch function

A possible instance of switch function, where the perceived object of $V_{1}$ is interpreted as the subject of the $V_{2}$ is exemplified in $(15)^{3}$. Here, two sub events are identified; push and open, where the object of the verb tsàmú 'push' functions syntactically as the subject of the $\mathrm{V}_{2}$ kwùlú $\bar{u}$ 'open'. Note that $\mathrm{V}_{2}$ is intransitive in non SVCs as in afe kwuluu 'The door opened'. Core arguments are not morphologically marked in Etulo, but rather specified by constituent order.

15) ó tsàmú òfè kwùlúū

3SG:SUBJ push door open

'He pushed the door open'

\section{SVC Components as Independent Verbs}

A SVC is basically made up of individual verbs which function independently as sole predicates in a clause. I illustrate below the use of the simple predicates kie 'take' and gia 'buy' as sole predicates in (16a-16b) and as a complex predicate in (16c).

16a) àdì kíe ànwúntò ḿgbí ánî

PN take cloth POSS 1SG

'Adi took my cloth'

16b) àdì gíá ànwúntò

PN buy cloth

'Adi bought a cloth'

16c) àdì lí kíe ànwúntò ḿgbắn gīā

PN HAB take cloth POSS:3SG sell

'Adi sells his clothes'

\section{Shared Negation}

Components of a SVC are not negated individually. Negation is marked once by the post sentential negation particle $b a$ and it has scope over all verbs in a SVC. Example:

17) ìsc̀sé kà kíé ènì fúé èsć bá

PN FUT take water sprinkle floor NEG

'Isese will not sprinkle water on the floor'

\section{E. Shared Tense-aspect Values}

Verb components of Etulo SVCs share the same tense aspect values. The preverbal or postverbal particles (the future $k a$, progressive $l e$, habitual $l i$ and perfect $w a$ ) that express tense-aspect are single marked (they occur just once in a SVC) and have scope over all verb series. Each of these particles has its peculiar distribution or occurrence pattern in relation to $\mathrm{V}_{1}$ and $\mathrm{V}_{2}$ (verb series).

The future morpheme $k a$ is linked to the first verb in a verb series. If on the other hand, the future marker directly precedes $\mathrm{V}_{2}$, there is a change in meaning. In the latter case, the construction changes from a SVC to a consecutive construction. In (18a), the future marker precedes $\mathrm{V}_{1}$ (gia 'buy') and has scope over the whole construction. In (18b) where it directly precedes $\mathrm{V}_{2}\left(n u\right.$ 'give'), the first verb $\left(\mathrm{V}_{1}\right)$ receives a past interpretation, thereby restricting the scope of the future morpheme to $\mathrm{V}_{2}$.

18a) àdì kà gíá àfề nù ánî

PN FUT buy book give 1SG

'Adi will buy me a book'

18b) àdì gíá àfè ká nù ánî

\footnotetext{
${ }^{3}$ a) In Etulo, the causative construction may pass as an example of switch function, whereby the object of $\mathrm{V}_{1}$ (causative verb) functions as the subject of $\mathrm{V}_{2}$ (main verb) as in àdì nù ánî mà àkw’̀ 'Adi made me cry'. The causative is formed by the causative verb nù and the main verb.

b) The stative form of the dynamic verb kwùlúu 'open' is realized by the stative verb la 'lie/lay' and the adjective ásísá 'open. Thus one can say ònùfề lá ásísá 'The door is open'.
} 
PN buy book FUT give $1 \mathrm{SG}$

'Adi bought a book and will give me/Adi bought a book to give me'

In both symmetric and asymmetric SVCs, the habitual morpheme li can only be linked to the first verb (19a). Ungrammatical constructions are realized when it is directly followed by the second verb in a verb series as illustrated in (19b).

19a) àdì lí kié ànwúntò ḿgbắn gīā

PN HAB take cloth POSS:3SG sell

'Adi sells his clothes'

19b) *àdì kíe ànwúntò ḿgbắn lí gīā

PN take cloth POSS:3SG HAB sell

'Adi sells his clothes'

For the progressive, the preverbal particle le directly precedes the main verb in some asymmetric SVCs especially directional SVCs (see 20a). With comparative (asymmetric) and most symmetric SVCs, it may directly precede either one of the verbs (see $20 \mathrm{~b}$ and $20 \mathrm{c})^{4}$.

20a) ínwúnô lé bùlù lúū

bird PROG fly go

'The bird is flying away'

20b) àdì lè kíe ànwúntò mígbắn gīā

PN PROG take cloth POSS:3SG sell

'Adi is selling his clothes'

20c) àdì kíe ànwúntò mugbắn lè gíá

PN take cloth POSS:3SG PROG sell

'Adi is selling his clothes'

The perfect marker occurs in the sentence final position of any SVC and has scope over the entire construction. Any change in its position of occurrence yields ungrammatical constructions (see 21a and 21b).

21a) á kīē ànwúntò ńtónê fàwá wà

3PL:SUBJ take cloth these tear PERF

'They have torn these clothes'

21b) *á kīề ànwúntò ńtón $\hat{\varepsilon}$ wà fàwá

3PL:SUBJ take cloth these PERF tear

'They have torn these clothes'

SVCs occur with all existing TA categories and in all moods without restrictions. In English for instance, an imperative construction such as go eat seems like a SVC at the surface level. However, one readily observes that such constructions are restricted to the imperative mood. Thus one cannot possibly say I went ate. Such restrictions are not characteristic of SVCs in Etulo and in languages where they occur. No temporal or aspectual contrast has been observed in Etulo SVCs in relation to different verb components. Serial verbs basically share the same TA values in constructions. The reverse is the case in languages like Ewe where in addition to being marked for the same categories, components of an SVC (VPs) can also be marked for different categories on the ground of semantic compatibility (see Ameka 2006).

For non-finite constructions (like the infinitive), the nominalising low tone prefix always attaches to the first verb in both symmetric and asymmetric SVCs. Examples:

22a) ínwúnó nâ mìná ò-bùlù lúū

bird that want PREF-fly go

'That bird want to fly away'

22b) àdí mìná ò-kíé ànwúntò ḿgbắn gīā

PN want PREF-take cloth POSS:3SG sell

'Adi wants to sell his cloth'

The distribution pattern of the tense-aspect markers is summarized in the table below:

\begin{tabular}{|c|c|c|}
\hline Tense aspect values & Pattern of occurrence & \\
\hline future - ka & linked to the first verb (SVC) & $\begin{array}{l}\text { linked to the second verb } \\
\text { (consecutive) }\end{array}$ \\
\hline habitual- li & linked to the first verb & $\begin{array}{l}\text { linked to the second verb } \\
\text { (ungrammatical) }\end{array}$ \\
\hline progressive - le & precedes the main verb in most asymmetric SVCs & $\begin{array}{l}\text { precedes either of the verbs in } \\
\text { some symmetric SVCs }\end{array}$ \\
\hline perfect - wa & \multicolumn{2}{|l|}{ post sentential - preceded by all SVC components } \\
\hline
\end{tabular}

\section{SVC TYPES}

\footnotetext{
${ }^{4}$ Concordant marking using the progressive morpheme (having the progressive morpheme precede each verb in an SVC) seems possible in Etulo but unnatural. A construction such as a kie ikinakpa le tse ons 'They are drying maize' is natural and preferred over a le kie ikinakpa le tse ons.
} 
SVCs are classified into different types using formal criteria such as composition, and contiguity. On the basis of the composition of an SVC, a two way split is made between asymmetric and symmetric types. Under the contiguity, a distinction is made between the contiguous and non-contiguous types. In Etulo, I make an additional distinction between the optional and obligatory SVCs. These SVC types are discussed in the subsequent sections.

\section{A. Asymmetric and Symmetric Divide}

Asymmetric SVCs in Etulo encode mostly single events expressed by a verb (main verb) which is further modified by another verb (minor verb). The minor verb specifies direction, comparison, benefactivity and instrumental role. Verbs that often occupy the minor slot in an asymmetric SVC include motion verbs (lúū, kغ̀ 'go', bá, wá, 'come', dzitá 'leave'), nū 'give' (benefactive), yà 'surpass' (comparative), kié 'take/carry' (instrumental) etc. A peculiar feature of this closed set of verbs is their capacity to co-occur with a wide range of major verbs in the asymmetric context, functioning as modifiers. Some of these modifying verbs occur following a fixed order; lúū and $\eta \grave{a}$ always follow the main verb while kié may occur as the first element in an asymmetric verb series. The transitivity value of the minor verb corresponds to that of the main verb but this is not always the case. There are instances in which components of an SVC have different transitivity values. Though the verb series of an asymmetric SVC may have different transitivity values, it is the transitive feature of the main verb that determines the transitivity value of the SVC as a whole. In (23) the main verb gía 'buy' is modified by the minor verb $n u$ 'give' for a benefactive meaning. Both verbs have transitive values. Example (24) illustrates the co-occurrence of the major verb kié 'carry' (transitive) and the motion verb lúu 'go' (intransitive) which functions as a modifier indicating direction; its transitive meaning stems from the main verb. In (25) one observes a combination of an intransitive main verb tsé 'run' and the transitive minor verb yà 'surpass' where the latter indicates comparison. The construction is however intransitive as a result of the point made earlier i.e. that the transitivity value of an asymmetric SVC is derived from that of the main verb. The foregoing reasserts the view that verbs do not necessarily retain their original transitivity status when they form an SVC. A strict categorization of main and minor verbs as obligatory occupants of the first and second verb slots following a particular order does not seem to apply in Etulo. Thus, a main or minor verb could occur either as the first or second element in an asymmetric SVC. Observe that kie which is the main verb in (24) appears as the $\mathrm{V}_{1}$ while $n u$ 'give' which is the main verb in (26) occurs as $\mathrm{V}_{2}$. What seems obvious is that certain verbs are more likely to occur as the first element than the second element and vice versa. Additionally, this possibility is not triggered by their function as main or minor verbs. Note that some of these minor verbs do not always function as modifiers in an SVC.

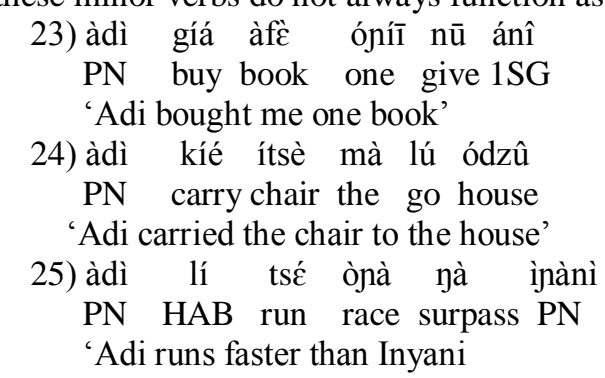

26) á kīē údzà lé nū m̀kpà

3PL:SUBJ take money PROG give credit

'They are lending money'

Symmetric SVCs encode more complex events that comprise sub events which occur sequentially and are semantically or pragmatically linked together. The components of a symmetric SVC come from an unrestricted class and have an equal status. To the class of symmetric SVC used to belong, a set of verbs that are now synchronically v+v

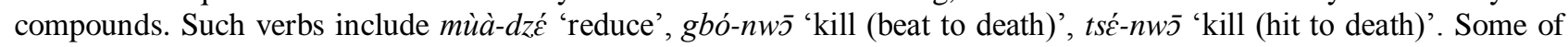
these verbs denote manner (cause-effect) as exemplified in (27) where $\mathrm{V}_{1}$ ts $\boldsymbol{\varepsilon}$ 'hit' encodes causation and $\mathrm{V}_{2}$ nw'́ 'kill' the result or effect of the event of hitting. Other symmetric verbs denote two consecutive aspects of an event as in (28), where the verbs $n \bar{u}$ and kwúlćš̌ mean 'stop'. These verb series may as well be reinterpreted as in a causative construction. Components of symmetric SVCs can both be contiguous or non-contiguous, and often share the same transitivity value. Such SVCs in Etulo might perhaps be in the process of lexicalization considering their idiomatic inclinations in some contexts. Take for instance the idiomatic meaning of the SVC àdì gbó áb̂̉ nū ìsèsé 'Adi begged Isese' which has the literal interpretation 'Adi clap hand give Isese/Adi clapped for Isese'. These serial verbs mostly share the same subject but not always the same object. Consider the following examples:

27) àdì tś́-nwō ìsèse

PN hit-kill PN

'Adi killed Isese'

28) ánî nù má kwúlésě

1SG:SUBJ make 3PL:OBJ stop

'I stopped them/ I made them stop'

29) á kīē ikínākpà lè tsé ònò

3PL:SUBJ take maize PROG spread sun 
'They are drying the maize'

\section{B. Optional and Obligatory SVCs}

There are many instances of optional and obligatory SVCs in Etulo especially with kié 'take' and other verbs like $n \bar{u}$ 'give'. The verb kié functions both as a main and minor verb in different semantic contexts and always occupies the first verb slot in SVCs while $n u$ occupies the final verb slot. The term optional SVC is used here for constructions in which the use of verb series is not obligatory. One observes the optional occurrence of kié 'take' in (30a). Its deletion in (30b) does not affect the meaning of the main verb fúe 'sprinkle'. The native speakers do not seem to perceive any semantic difference between both constructions. In the words of my informants, sentence (30b) is a shorter way of saying (30a). From a pragmatic point of view, however, it could be that the co-occurrence of the minor verb kié with fúe indicates an elaborate breakdown or description of the event of sprinkling which involves first the subevent of taking (scooping) water and then sprinkling it. This can equally account for the optional co-occurrence of kié with $n \bar{u}$ in (31a and 31b). In contrast, the omission of the verb kié in ( $32 \mathrm{~b})$ changes the meaning from 'sell' to 'buy'. The co-occurrence of kié with gía in an SVC is therefore obligatory for the realization of the verb sell (see 32a). The combination of gbó ábs 'clap hand' and $n \bar{u}$ 'give' in (33) realizes the idiomatic meaning beg which can be re-interpreted as clap if one of the serial verbs ( $n \bar{u}$ ' give) is deleted.

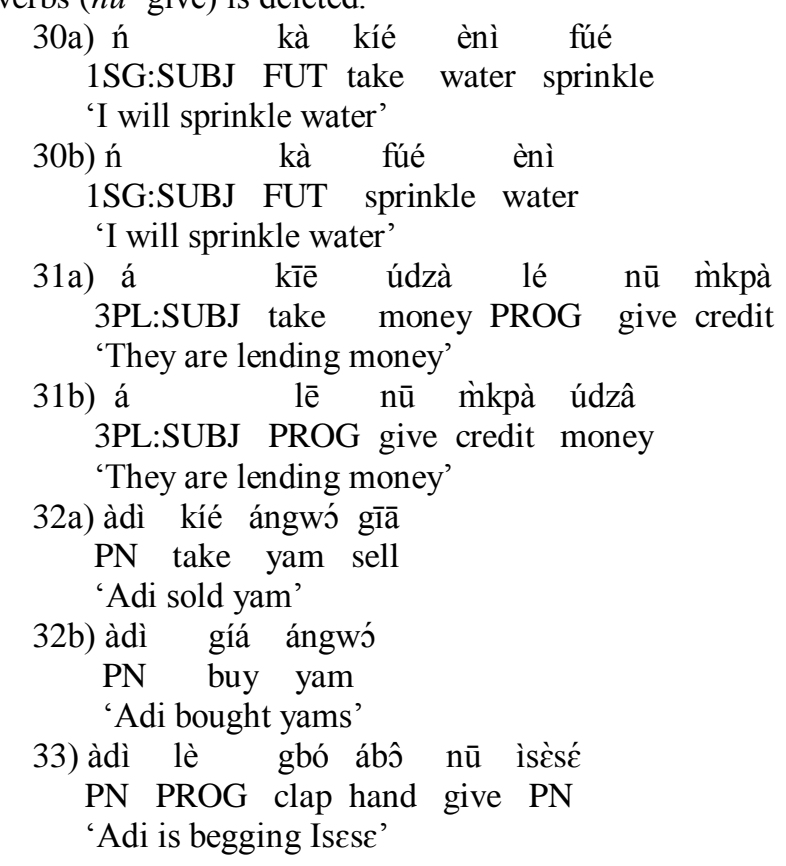

\section{Contiguity and Wordhood}

The components of an SVC in Etulo could be contiguous or non-contiguous. Contiguous SVCs allow a direct juxtaposition of serial verbs. The reverse is the case for non-contiguous SVCs. With the exception of lexicalized serial verbs (now compounds) which comprise one grammatical word (made up of two phonological words), Etulo SVCs comprise multiple words. They may be separated by other constituents such as prepositions, direct objects, complements etc. Example (34) illustrates two identical SVCs that involve different positioning of the serial verbs. In sentence (34a), the SVC comprises two verbs kié 'take' and fàwá 'tear' which are contiguous. In (34b), these same verbs are separated by the direct object ànwúntò 'cloth' and are therefore, non-contiguous. The contiguity of serial verbs in such cases is relatively optional. In example (35a) however, the non-contiguity of the serial verbs tá 'scream' and wó 'put' is obligatory. Both verbs are separated by the nominal complement èlâ 'voice'. The direct juxtaposition of both verbs results in ungrammaticality $(35 b)$.

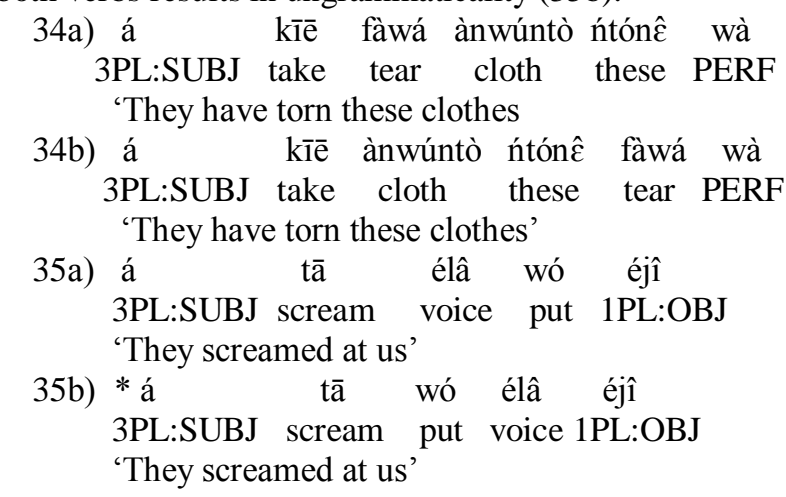




\section{DiFFERENTIATING SVCS FROM CONSECUTIVE CONSTRUCTIONS}

In many verb serialising languages of West Africa such as Igbo, Ewe, Akan, a group of roughly similar constructions which involve the occurrence of verb sequences in a single clause are common place. Aikhenvald (2008) adopts the term multi-verb construction an umbrella term for such constructions. They include serial verb constructions, consecutive, and overlapping constructions. Two forms of multi-verb constructions are identified in Etulo; the consecutive and serial verb constructions. Basically, consecutive constructions involve two or more verbs that express related events which may occur in succession or simultaneously, while serial verb constructions involve a sequence of verbs that may jointly serve as a single predicate or denote a unified or related phases of an event. The consecutive constructions of (36a) and (36b) express a series of related events that occur sequentially such as steal-run and fetchwash.

36a) àdì jí úmí ánî údzà dí kié tsé ònà lúū

PN steal theft ISG:POSS money CORD take run race go

'Adi stole my money and ran away'

36b) ábû mùà ènì nwù ínć wà

2SG:SUBJ fetch water wash face PERF

'You have fetched water and washed your face'

Both construction types share a lot of similarities which can be somewhat misleading. They have in common the sequential occurrence of two or more verbs in a single clause, shared arguments, and shared temporal values. They however differ in several ways. One of the major distinctions made between the consecutive and serial verb constructions in Etulo is instantiated by the optional occurrence of a linking element or connector di in some consecutive constructions (37a-b). On the contrary, such linking element is obligatorily absent in SVCs (38a-b). Other points of differentiation are derived from the inherent nature of the event expressed by both constructions, and the optionality of single vs concordant marking of tense-aspect values. Consider the following examples:

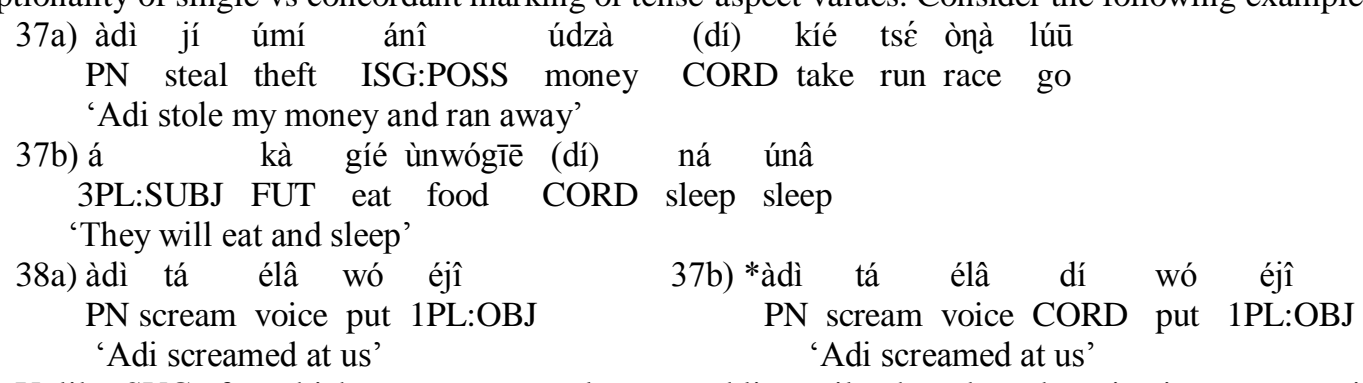

Unlike SVCs for which tense-aspect values are obligatorily shared, verb series in a consecutive construction may have the same or different temporal/aspectual values. In (39a), the future marker $k a$ precedes $\mathrm{V}_{1}$ (kié 'take') and has scope over the whole SVC. In the consecutive construction of (39b) where the future marker directly precedes $\mathrm{V}_{2}$ (fúe 'sprinkle)' the first verb $\left(\mathrm{V}_{1}\right)$ receives a past interpretation, thereby restricting the scope of the future morpheme to $\mathrm{V}_{2}$.

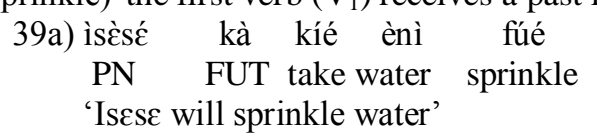

39b) ìsčsć kíé ènì kà fúé

PN take water FUT sprinkle

'Isese took water to sprinkle'

Lit: 'Adi took water and will sprinkle'

SVCs allow only the single marking of tense-aspect values as in (40). On the contrary, the consecutive construction allows both the single and concordant marking of tense aspect values. In (40b) for instance, the concordant marking with the progressive marker $l e$ is optional.
40a) àdì lé bùlù lúū
PN PROG fly go
4Adi àdì flying away' lè gbónwó (lè) kié wók̄ is ígbé
41)
PN PROG beat-kill PROG take put in bag
'Adi is killing and putting inside a bag'

The similarities and differences of multi-verb constructions are further summarized in the table below: 
TABLE II

\begin{tabular}{|l|l|l|}
\hline Features & Consecutive & SVCs \\
\hline shared argument (subject) & Yes \\
\hline monoclausal interpretation & Yes & Yes \\
\hline Marker(s) of syntactic dependency & Yes & No \\
\hline Shared temporal frame & (optional) & Yes \\
\hline Single marking of tense-aspect & possible & Yes \\
\hline Express a unified event & Yes (optional) & Yes \\
\hline $\begin{array}{l}\text { Individual verbs can function as independent verbs in simple } \\
\text { clauses (in same form) }\end{array}$ & Ye & Yes \\
\hline
\end{tabular}

\section{CONCLUSION}

The serial verb construction is clearly a productive grammatical device in Etulo which expresses a variety of semantic notions. Some of its semantic functions make up for the paucity of other grammatical categories in Etulo. In many ways, the identified features of SVCs in Etulo correspond with the cross linguistic characterization of SVCs. The functional motivation for the common occurrence of SVCs in Etulo is partly tied to the need of speakers to relay events which are considered closely related for pragmatic or cultural reasons. Some symmetric SVCs comprise verb sequences that realise an idiomatic meaning rather than unified or related sub events. This may be attributed to the grammatical process of lexicalisation. Further investigation is required in the characterization of Etulo SVCs in the area of grammaticalisation and lexicalisation, argument structure of SVCs, the motivation for the occurrence of optional SVCs in Etulo, the distinction between SVCs and other multi-verb constructions amongst others.

\section{REFERENCES}

[1] Aikhenvald, A. Y. (2006). Serial verb construction in typological perspective. In Aikhenvald, A.Y \& R.M.W Dixon (eds.), Serial verb construction: a cross linguistic typology. Oxford: Oxford University Press. 1-60

[2] Ameka, Felix K. (2006). Ewe Serial Verb Construction in their Grammatical context. In Aikhenvald, A \& Dixon R.M.W (eds.), Serial verb construction: a cross linguistic typology. Oxford: Oxford University Press. 124-141.

[3] Ameka, Felix K. (2008). Multiverb Construction in a West African areal typological perspective. In Dorothee Beermann and Lars Hellan (eds.), TROSS 03 Proceedings. Trondheim: NTNU.

[4] Baker, B. \& Harvey, M. (2010). Complex predicate formation. In Mengistu, A., Baker, B \& Harvey, M (eds.), Complex Predicates: Cross-linguistic Perspectives on Event Structure.Cambridge: Cambridge University Press. 13-47.

[5] Ezenwafor Chikelu I. (2017). A grammatical sketch of Etulo. Scuola Normale Superiore, Pisa Italy PhD dissertation.

[6] Foley, W. A. (2010). Events and serial verb constructions. In Mengistu, A., Baker, B \& Harvey, M (eds.), Complex predicates: cross-linguistic perspectives on event structure. Cambridge: Cambridge University Press. 79-109.

[7] Hellwig, B. (2006). Serial verb construction in Goemai. In Aikhenvald, A.Y and R.M.W. Dixon (eds.), Serial verb constructions: a cross linguistic typology. Oxford University Press. 89 -106.

[8] Lord, C. (1993). Historical change in serial verb constructions. Typological studies in language 26. Amsterdam: John Benjamins

[9] Matthew, S. (2006). On serial verb constructions in Cantonese. In Aikhenvald, A.Y \& R.M.W Dixon (eds.), Serial verb construction: a cross linguistic typology. Oxford: Oxford University Press. 69-87

[10] Yeung, K. (2003). Universal vs language specific properties of grammaticalized complementizers: two case studies in multifunctionality. University of Hong kong M.Phil thesis.

Chikelu Ihunanya Ezenwafor is presently a lecturer at the Department of Linguistics, Nnamdi Azikiwe University. 